\title{
PENDIDIKAN BERBASIS KECERDASAN RUHANIAH (Membentuk Insan Paripurna/ Insan al-Kamil)
}

\author{
Deswita \\ Jurusan Tarbiyah Sekolah Tinggi Agama Islam Negeri Batusangkar \\ Korespondensi: Jl. Lasykar No. 80 Koto Gadis Lima Kaum Batusangkar \\ e-mail: deswita.ma@yahoo.com
}

\begin{abstract}
This article aims at analyzing spiritual intelligence based education since the basically, the goal of education is to build perfect human (insan kamil). Such goal can be realized as long as the pupils are able to integrate all of their potential intelligences. Those potentials are physical, emotional, intellectual and spiritual intelligences. The integration of those intelligences is called spiritual intelligence. Furthermore, spiritual intelligence based education basically encourages the pupils to apply the values of spiritual (ilahiyat) in establishing relationship among humans and other creatures on the basis of God's mercy.
\end{abstract}

Kata kunci: pendidikan, kecerdasan ruhaniah

\section{PENDAHULUAN}

$\mathrm{D}$ alam pandangan yang berkembang dalam masyarakat umum, pendidikan nasional dalam berbagai jenjangnya, khususnya jenjang menengah dan tinggi, dianggap "telah gagal" dalam membentuk peserta didik yang memiliki moral, akhlak, dan budi pekerti yang baik. Lebih jauh lagi, banyak peserta didik dinilai tidak hanya kurang memiliki kesantunan, baik di sekolah, sekolah, dan di lingkungan masyarakat, tetapi juga sering terlibat dalam tindak kekerasan missal, seperti tawuran.

Selama ini, pandangan simplistik yang berkembang di dalam masyarakat menganggap, bahwa kemerosotan akhlak, moral, dan etika peserta didik disebabkan gagalnya pendidikan agama di sekolah. Memang harus diakui, dalam batas tertentu, pembelajaran pendidikan agama memiliki kelemahan-kelemahan tertentu, sejak dari jumlah jam yang sangat minim, materi pendidikan agama yang terlalu banyak teori, sampai kepada pendekatan pendidikan agama yang cenderung bertumpu pada aspek kognitif daripada aspek afeksi dan psikomotorik peserta didik. Berhadapan dengan berbagai kendala, dan masalah-masalah seperti ini, pendidikan agama menjadi tidak atau kurang fungsional dalam membentuk akhlak, moral, dan bahkan kepribadian peserta didik.

Di lembaga pendidikan kita baik dari tingkatan dasar sampai tingkat kuliah, pendidikan nilai atau moral jarang di jadikan patokan dalam pembangunan pendidikan dan bahkan tidak sama sekali menjadi target utama dalam proses kependidikan. Pendidikan kita masih lebih percaya, bahwasanya keberhasilan pendidikan adalah diten tukan sejauh mana anak didik mengetahui serta menghafal materi-materi pelajaran dan seberapa bagus nilai raportnya. Orientasi 
pendidikan nasional lebih banyak di dasarkan pada pengembangan akademik an sich. Sedangkan pendidikan moral, penataan hati, pembangunan mental serta pendidikan agama masih sangat jauh dari praktek kependidikan. Pendidikan agama hanya sebatas di jadikan sebagai pengantar ilmu pengatahuan. Anak didik hanya di ajarkan sebatas mengatahui tidak masuk bagaimana anak dapat memahami dan mengamalkannya. Ini sungguh sangat ironis sekali Apalagi bangsa ini mayoritas adalah bangsa yang beragama (Islam).

Kegagalan dalam penanaman nilainilai (ajaran moral) serta pembangunan mental anak dan lain-lainnya saat ini telah kita rasakan bersama. Krisis ekonomi yang terus berkepanjangan, tawuran antar pelajar serta dan yang lebih parah maraknya perilaku seksual di tingkatan remaja, ini merupakan potret dari kegagalan pendidikan dalam mentranformasikan nilai sebagai pusat pemberdayaan manusia. Lemahnya bekal moral keagamaan semacam itu pada gilirannya akan melahirkan individuindividu lemah moral yang kehilangan eksisistensinya sebagai manusia sejati yang selalu di landasi oleh semangat kejujuran.

Dalam kerangka ini maka profil yang harus di lahirkan oleh pendidikan kita adalah figur intelektual-moralisagamis yang senantiasa mamahami tujuan esensial dari pendidikan untuk menerjamahkan makna kemashlahatan dan keadilan. Dari sini maka sangat jelas bahwa arah pendidikan adalah pada hakikatnya mengerucut pada satu arah melahirkan generasi berbobot atau berisi dan beriman yang memiliki komitmen dalam menciptakan kemaslahatan, Pendidikan adalah sarana untuk membentuk kesadaran hidup untuk kembali pada hakikat kemanusiaannya.

Itulah menurut hemat penulis yang menjadi subtansi pendidikan dan target sasaran dari pendidikan. Dan salah satu cara yang mungkin bisa di pakai untuk mencapai cita ideal tersebut adalah dengan menerapkan pendidikan emosional spiritual quotient dalam ranah pendidikan kita

\section{DASAR PEMIKIRAN}

Sejauh menyangkut krisis moral dan akhlak peserta didik, terdapat beberapa masalah pokok yang turut menjadi akar krisis moral dan akhlak di lingkungan pendidikan nasional. (Azyumardi Azra, 2008). Pertama, arah pendidikan telah kehilangan objektivitasnya. Sekolah dan lingkungannya tidak lagi merupakan tempat peserta didik melatih diri untuk berbuat sesuatu berdasarkan nilai-nilai moral dan akhlak, di mana mereka mendapat koreksi tentang tindakan-tindakannya; salah atau benar, baik atau buruk. Dengan kata lain, terdapat keengganan dilingkungan guru untuk menegur peserta didik yang melakukan tindakan-tindakan yang kurang pada tempatnya.

Kedua, proses pendewasaan diri tidak berlangsung baik di lingkungan sekolah. Lembaga pendidikan kita umumnya cenderung lupa pada fungsinya sebagai tempat sosialisasi dan pembudayaan peserta didik (enkulturisasi). Selain berfungsi pokok untuk mengisi kognisi, afeksi dan psikomotorik peserta didik, sekolah sekaligus juga bertugas untuk mempersiapkan mereka meningkatkan kemampuan merespon dan memecahkan masalah-masalah dirinya sendiri maupun orang lain. Dengan demikian, terjadi proses "pendewasaan" peserta didik secara bertahap dalam memecahkan masalah yang mereka hadapi secara bertanggung jawab. Pemecahan masalah secara tidak bertanggung jawab, seperti melalui tawuran dan bentukbentuk kekerasan lain, merupakan indi- 
kator tidak terjadinya proses pendewasaan melalui sekolah.

Ketiga, proses pendidikan di sekolah sangat membelenggu peserta didik, bahkan juga para guru. Hal ini bukan hanya karena formalisme sekolahmisalnya dalam hal administrasi, kurikulum dan silabus yang cenderung sangat ketat, juga karena beban kurikulum yang sangat berat (overloaded). Akibatnya, hampir tidak tersisa lagi ruang bagi peserta didik untuk mengembangkan imajinasi dan kreativitas kognisi, afeksi dan psikomotoriknya. Lebih para lagi, interaksi yang berlangsung di sekolah telah hampir kehilangan human dan personal touchnya. Jadinya proses pendidikan di sekolah hampir sama dengan interaksi manusia di pabrik yang akan menghasilkan produk-produk serba mekanistis dan robotis.

Keempat, beban kurikulum yang demikian berat, lebih parah lagi, hampir sepenuhnya diorientasikan pada pengembangan ranah kognitif belaka. Dan itu pun disampaikan melalui pola delivery system. Pada pihak lain, ranah afeksi dan psikomotorik hampir tidak mendapat perhatian untuk pengembangan sebaikbaiknya. Padahal pengembangaan kedua ranah ini sangat penting dalam pembentukan akhlak, moral, budi pekerti atau singkatnya, watak, dan karakter yang baik.

Kelima, kalaupun ada materi yang menunmbuhkan rasa afeksi- seperti mata pelajaran agama, umumnya disampaikan dalam bentuk verbal, yang juga disertai dengan rote-memorizing. Akibatnya bisa diduga, mata pelajaran agama cenderung hanya untuk diketahui dan dihafalkan agar lulus ujian; tetapi tidak untuk diinternalisasikan dan dipraktekkan, sehingga betul-betul menjadi bagian yang tidak terpisahkan dari diri setiap peserta didik.

Keenam, pada saat yang sama para peserta didik dihadapkan kepada nilai- nilai yang sering bertentangan (contradictory set of values). Pada satu pihak, mereka diajarkan para guru pendidikan agamanya untuk bertungkah laku yang baik, jujur, hemat, rajin, disiplin, dan sebagainya, tetapi pada saat yang sama, banyak orang di lingkungan sekolah justru melakukan hal-hal yang bertentangan.

Ketujuh, selain itu para peserta didik juga mengalami kesulitan dalam mencari contoh teladan (uswatun hasanah) di lingkungannya. Mereka mungkin menemukan teladan yang baik di lingkungan sekolah, di dalam diri guru tertentu. Tetapi mereka kemudian sulit menemukan keteladanan dalam lingkungan di luar sekolah. Karena itulah, tak jarang terlihat bahwa banyak remaja justru menemukan tokoh-tokoh teladan diantara tokoh-tokoh yang sudah wafat.

Ketujuh masalah di atas, saling berkaitan satu sama lainnya. Dan sebab itu, upaya mengatasinya tidak bisa dilakukan secara parsial. Bahkan dapat dikatakan, pemecahan masalah-masalah besar itu meniscayakan refomasi pendidikan nasional secara keseluruhan.

Bagaimanapun, krisis moral, karakter, dan akhlak anak didik jelas berkaitan dengan krisis-krisis lain yang dihadapi pendidikan nasional pada umumnya. Karena itu, kalau kita mau menilai secara adil dan fair- meskipun makro- krisis moral dan akhlak peserta didik merupakan cermin dari krisis lebih luas, yang terdapat dan berakar kuat dalam masyarakat umumnya. Dengan kata lain, krisis moral dan akhlak di antara peserta didik pada berbagai jenjang pendidikan- khususnya jenjang menengah dan tinggi- bagaimanapun merupakan cermin dari krisis moral dan akhlak dalam masyarakat lebih luas. Sebab itu pula, bias juga diasumsikan, bahwa upaya mengatasi seperti itu, tidak memadai jika hanya dilakukan hanya di lingkungan sekolah. Kita harus menyem- 
buhkan krisis moral dan akhlak dalam masyarakat luas; dalam rumah tangga dan lingkungan lainnya.

Meski demikian, sekolah bukan tidak berkewajiban untuk memulai upaya mengatasi krisis moral dan akhlak itu, setidaknya dengan memulainya di lingkungan sekolahnya sendiri. Walaupun upaya itu belum tentu dapat menyembuhkan semua krisis, tetapi karena sekolah memiliki posisi yang sangat strategis dalam masyarakat, upaya sekolah dapat menjadi titik pusat dan awal dari usaha penyembuhan krisis dalam masyarakat kita secara menyeluruh.

\section{KECERDASAN RUHANIAH}

Kecerdasan ruhaniah pada dasarnya merupakan gabungan dari semua potensi kecerdasan yang dimiliki oleh manusia, yaitu kecerdasan fisik, emosi, intelektual, dan spiritual.

\section{Kecerdasan Emosi (EQ)}

Kecerdasan Emosi (EQ) adalah kemampuan merasakan, memahami, dan secara efektif menerapkan daya dan kecakapan emosi sebagai sumber energi, informasi, koneksi, dan pengaruh manusia. Emosi adalah bahan bakar yang tidak tergantikan bagi otak agar mampu melakukan penalaran yang tinggi. Emosi menyulut kreatifitas, kolaborasi, inisiatif, dan transformasi; sedangkan penalaran logis berfungsi mengatasi dorongandorongan yang keliru dan menyelaraskan dengan proses, dan teknologi dengan sentuhan manusiawi. Emosi juga merupakan salah satu kekuatan penggerak. Bukti-bukti menunjukkan bahwa nilainilai dan watak dasar seseorang dalam hidup ini tidak berakar pada IQ tetapi pada kemampuan emosional. (Cooper \& Sawaf, 1998, 15)

Jika kecerdasan intelektual diwujudkan dalam berfikir, maka kecerdasan emosi diwujudkan dalam merasa. Jika kecerdasan intelektual bisa diasah, begitu juga dengan kecerdasan emosi dapat diransang. Kecerdasan emosi ditandai dengan kemampuan pengendalian emosi ketika menghadapi kenyataan-kenyataan mental, seperti: menyenangkan, menakutkan, menjengkelkan, memilukan, dsb. (Ahmad Mubarok, 2010; 65)

\section{Kecerdasan Spiritual}

Danah Zohar dan Ian Marshall mendefinisikan kecerdasan spiritual adalah kecerdasan untuk menghadapi persoalan makna atau value, yaitu kecerdasan untuk menempatkan perilaku dan hidup kita dalam konteks makna yang lebih luas dan kaya, kecerdasan untuk menilai bahwa tindakan dan jalan hidup seseorang lebih bermakna dibandingkan dengan yang lain.. SQ adalah landasan yang diperlukan untuk memfungsikan IQ dan EQ secara efektif. Bahkan SQ merupakan kecerdasan tertinggi. (Danah Zohar dan Ian Marshall, 1999)

Sementara itu Ary Ginanjar mendefinisikan kecerdasan spiritual adalah kemampuan untuk memberi makna ibadah terhadap setiap perilaku dan kegiatan, melakukan langkah-langkah dan pemikiran yang bersifat fitrah, menuju manusia yang seutuhnya (hanif), dan memiliki pola pemikiran tauhidi (integralistik), serta berprinsip "hanya karena Allah”. (Ary Ginanjar, 2001, 57)

\section{Emotional and Spiritual Quotient (ESQ)}

ESQ merupakan penggabungan dua kekuatan untuk menemukan pengetahuan yang benar dan hakiki. Jika dalam EQ merupakan hubungan antara manusia dengan manusia, SQ merupakan hubungan antara manusia dengan Tuhan, maka ESQ merupakan hubungan antara manusia- manusia- dan Tuhan.

Di dalam Islam hal-hal yang berhubungan dengan kecakapan emosi dan 
spiritual seperti konsistensi (istiqomah), kerendahan hati (tawadhu'), berusaha dan berserah diri (tawakkal), ketulusan / sincerety (keikhlasan), totalitas (kaffah), keseimbangan (tawazun), integritas dan penyempurnaan (ihsan), semua itu dinamakan dengan Akhlakul karimah. Dalam kecerdasan emosi, hal-hal yang disebutkan di atas itulah yang dijadikan sebagai tolak ukur kecerdasan emosi (EQ), seperti, integritas, komitmen, ketulusan, dan totalitas. Oleh karena itu bahwa kecerdasan emosi sebenarnya adalah akhlak dalam Islam, di mana hal ini telah diajarkan oleh Rasulullah SAW seribu empat ratus tahun yang lalu jauh sebelum konsep EQ diperkenalkan saat ini sebagai sesuatu yang lebih penting dari IQ. Inilah yang dinamakan dengan ESQ (Ary Ginanjar, 2001, 201).

Di dalam Islam, semua kecakapan emosi dan spiritual yang merupakan konsep ESQ, sebagaimana yang telah dijelaskan di atas, inilah yang dinamakan dengan "Kecerdasan Ruhaniah"/ trancedental intelligence (TQ), Adapun yang dimaksud dengan kecerdasan ruhaniah adalah kemampuan seseorang untuk mendengarkan hati nuraninya atau bisikan kebenaran yang meng-Ilahi dalam cara dirinya mengambil keputusan atau melakukan pilihan-pilihan, berempati dan beradaptasi. (Toto Tasmara, 2001, 47)

Kecerdasan ruhaniah sangat ditentukan oleh upaya membersihkan dan memberikan pencerahan qalbu (tazkiyah, tarbiyatul quluub) sehingga mampu memberikan nasehat dan arah tindakan serta caranya kita mengambil keputusan. Qalbu harus senantiasa berada pada posisi menerima curahan cahaya ruh yang bermuatan kebenaran dan kecintaan kepada Ilahi.

Dari sudut pandang kita sebagai seorang Muslim, kecerdasan ruhaniah adalah kecerdasan yang berpusat pada rasa cinta yang mendalam kepada Allah dan seluruh ciptaan-Nya, Sebuah keyakinan yang mampu mengatasi seluruh perasaan yang bersifat jasadi, bersifat sementara dan fana. Kecerdasan ruhaniah justru merupaakan esensi dari seluruh kecerdasan yang ada. Atau dapat dikatakan, sebagai kecerdasan spiritual plus, dan plusnya itu berada pada nilai-nilai keimanan kepada Ilahi. Pesan-pesan keilahian itu telah melekat secara fitrah pada saat manusia dalam alam ruhani.

\section{PENDIDIKAN YANG BERBASIS KECERDASAN RUHANIAH}

Pendidikan dapat dipandang dari berbagai sisi, yaitu sisi individu, masyarakat, dan sisi interaksi individu dan masyarakat. Bila dilihat dari sisi individu, pada dasarnya manusia mempunyai sejumlah kemampuan yang dapat diangkat dan dikembangkan melalui pendidikan. Sehingga dalam hal ini pendidikan diartikan sebagai sebuah proses untuk menemukan dan mengembangkan kemampuan-kemampuan seperti; kecerdasan, kepribadian, dan kreatifitas anak didik. (Hasan Langgulung, 1991;359)

Sedangkan di sisi pandangan masyarakat, bahwa dari kemampuan asal individu perlu adanya proses pemasukan dari alam di luar sisi manusia. Berarti pendidikan dimaksudkan sebagai proses pemindahan kesimpulan yang tidak bisa atau tidak dilakukannya sendiri, atau disebut juga pewaris budaya. (Hasan Langgulung, 1991; 360)

Adapun dari sisi ketiga, yakni interaksi individu dan masyarakat, dipandang bahwa pendidikan merupakan proses memberi dan mengambil antara manusia (individu) dan lingkungannya. Sehingga dengan pendidikan, individu tersebut dapat mengembangkan dan menciptakan berbagai hal yang diperlukan untuk merubah dan memperbaiki kondisi-kondisi kemanusiaan dan ling- 
kungannya. (Hasan Langgulung, 1991; 361)

Dari ketiga pendekatan pemaknaan tentang pendidikan, dapat disimpulkan bahwa pendidikan dimaksudkan sebagai proses pengembangan potensi peserta didik yang dapat dipengaruhi oleh warisan budaya yang tercipta sebelumnya atau individu lain dan lingkungan yang ada pada saat peserta didik itu berada. Dalam pengertian lain, pendidikan merupakan usaha dari manusia dewasa membimbing, melatih,mengajar, dan menanamkan nilai-nilai pada generasi sesudahnya. (Zuhairini, dkk, 1992:11)

Dari berbagai gambaran tentang pendidikan diatas, maka dapat dipahami bahwa secara filosofis, pendidikan itu bertujuan untuk membentuk al-insan alkamil atau manusia paripurna. Manusia sempurna adalah manusia yang hidup seimbang dan utuh dengan seluruh kecerdasannya. Kecerdasan fisikal, intelektual, emosional, dan spiritual (PQ, IQ, $\mathrm{EQ}$, dan SQ). Kecerdasan fisik dan intelektual umumnya kita dapatkan melalui bangku pendidikan, kecerdasan emosional dari pergaulan, dan kecerdasan spiritual dari kematangan pengalaman hidup. (Erbe Sentanu, 2007: 22)

Beranjak dari konsep di atas, maka setidaknya- pendidikan Islam diarahkan pada dua dimensi, yaitu: pertama, dimensi dialektika horizontal terhadap sesamanya. Kedua, dimensi ketundukan vertikal kepada Allah. (A.M.Saefuddin, 1991: 126).

Pada dimensi pertama, pendidikan hendaknya mengembangkan pemahaman tentang kehidupan konkret dalam konteks dirinya, sesama manusia, dan alam semesta. Akumulasi berbagai pengetahuan, keterampilan dan sikap mental merupakan bekal utama pemahaman terhadap makna kehidupan. Sementara pada dimensi kedua, memberi arti bahwa pendidikan sains dan teknologi, selain menjadi alat untuk memanfaatkan, me- melihara dan melestarikan sumber daya alami, dirinya juga menjadi jembatan dalam mencapai hubungan yang abadi dengan Sang Pencipta. Untuk itu, pelaksanaan ibadah dalam arti seluas-luasnya adalah merupakan sarana yang dapat menghantarkan manusia kea rah ketundukan vertikal kepada Khaliknya.

Format pendidikan yang harmonis dan integral, merupakan karakteristik pendidikan Islam yang ideal dan efektif dalam mencapai tujuan yang diinginkan, yaitu terciptanya peserta didik yang yang berkepribadian insan kamil. Karateristik tersebut meliputi; Pertama, penekananya di samping pada aspek sosial, individu, budaya, politik, ekonomi, juga terutama pada aspek ibadah dan akhlaq alkarimah. Kedua, adanya pengakuan pada potensi (fitrah) manusia, baik secara pisik maupun psikis yang diharmonisasikan secara integral dalam melihat peserta didik sebagai khlaifah dan makhluk Allah di muka bumi.Ketiga, pendidikan hendaknya menekankan pada tumbuhnya rasa tanggung jawab pada diri peserta didik, baik terhadap dirinya, masyarakat, alam semesta, maupun kepada Allah (Khalik). (Azyumardi Azra, 1999; 10)

Untuk mencapai semua karakteristik di atas, maka kita harus memanfaat " Kekuatan Ruhaniah" yang telah dianugerahkan Allah kepada kita. Kekuatan ruhaniah itulah yang merupakan inti dari kecerdasan yang dimiliki oleh manusia. Hal ini telah diberikan isyaratkan oleh Allah dalam firman-Nya:

"Kemudian Dia menyempurnakannya dan meniupkannnya ke dalam (tubuh) nya roh (ciptaan)-Nya. Dia menjadikan bagi kamu pendengaran, penglihatan, dan hati; (tetapi) kamu sedikit sekali bersyukur." (as-Sajadah: 9)

Ayat ini memberikan isyarat bahwa manusia terlahir dengan dibekali kecerdasan yang terdiri dari lima bagian utama kecerdasan, yaitu 
sebagai berikut: (Toto Tasmara, 2001: 49).

1. Kecerdasan Ruhaniah (spiritual intelligence): kemampuan seseorang untuk mendengarkan hati nuraninya, baik buruk dan rasa moral dalam caranya menempatkan diri dalam pergaulan.

2. Kecerdasan intelektual: kemampuan seseorang dalam memainkan potensi logika, kemampuan berhitung, menganalisa dan matematika (logical-mathematical intelligence).

3. Kecerdasan emosional (emotional intelligence): kemampuan seseorang dalam mengendalikan diri (sabar) dan kemampuan dirinya untuk memahami irama, nada, musik, serta nilai-nilai estetika.

4. Kecerdasan social: kemampuan seseorang dalam menjalin hubungan dengan orang lain, baik individu maupun kelompok. Dalam kecerdasan ini termasuk pula interpersonal, intrapersonal skill, dan kemampuan berkomunikasi ( $l i$ nguistic intelligence).

5. Kecerdasan fisik (bodily-kinesthetic intelligence): kemampuan seseorang untuk mengkoordinasikan dan memainkan isyarat-isyarat tubuhnya.

Seluruh kecerdasan tersebut, harus berdiri di atas kecerdasan ruhaniah sehingga potensi yang dimilikinya menghantarkan dirinya kepada kemualiaan akhlak. Empat kecerdasan yang dikendalikan oleh hati nurani akan memberikan nilai tambah bagi kesejahteraan dan perdamaian manusia. Kecerdasan ruhaniah adalah kecerdasan yang paling sejati tentang kearifan dan kebenaran serta pengetahuan Ilahi. Kecerdasan ini menimbulkan rasa cinta yang sangat mendalam terhadap kebenaran (mahabbah lillah).
Berangkat dari uraian di atas, maka untuk selalu terasahnya kecerdasan ruhani peserta didik maupun pendidik itu sendiri, ada beberapa hal yang perlu kita lakukan dalam proses pendidikan, yaitu:

\section{Meneladani dan mengaktualisasikan Akhlak Rasulullah SAW dalam kehidupan sehari-hari.}

Akhlak Rasulullah SAW merupakan bentuk hidup dari aktualisasi AlQur'an yang sangat multidimensi dan sangat luas batasannya. Karena itu, memahami dan mengamalkan Al-Qur'an dengan merujuk pada konteks perilaku Rasulullah sebagai teladan yang sempurna, merupakan bagian dari upaya setiap muslim yang ingin mengaktualisasikan iman dan taqwanya secara nyata. Dalam mengasah kecerdasan ruhani, di bawah ini akan dibahas dimensi atau kandungan akhlak Rasulullah. Dengan demikian, diharapkan dapat menjadi kebutuhan dan kebiasaan perilaku yang mmenghujam dalam hati sanubari. Karena merasakan kebahagiaan tiada tara bagi seorang muslim untuk meneladani sikap dan perilaku Rasulullah saw.

\section{Shiddiq}

Suatu hal yang tidak boleh kita lupakan dalam proses pendidikan adalah menanamkan nilai-nilai kejujuran dalam hidup ini. Jujur pada diri sendiri, jujur pada orang lain dan jujur kepada Allah. Karena kejujuran adalah komponen ruhani yang memantulkan berbagai sikap terpuji. Orang-orang yang mempunyai kejujuran ini adalah orang-orang yang berani menyatakan sikap secara transparan, terbebas dari segala kepalsuan dan penipuan, hatinya selalu terbuka dan bertindak lurus. Sehingga mereka memiliki keberanian moral yang sangat kuat.

Kejujuran bukan datang dari luar tetapi ia adalah bisikan qalbu yang terusmenerus mengetuk-ngetuk dan memberikan percikan cahaya Ilahi. Kejujuran 
bukanlah sebuah keterpaksaan, melainkan sebuah panggilan dari dalam dan merupakan sebuah keterikatan (i'tiqad).

Perilaku yang jujur adalah perilaku yang diikuti dengan sikap tanggung jawab atas apa yang dia perbuat. Dia siap menghadapi segala resiko dan seluruh akibatnya dengan penuh suka cita. Tidak pernah terpikirkan olehnya untuk melemparkan tanggung jawab kepada orang lain.

Salah satu cara yang paling mujarab untuk mengasah kejujuran ini adalah dengan memaknai shalat. Karena salah satu dimensi moral yang dilahirkan shalat adalah kejujuran, keikhlasan, dan ketabahan. Seseorang yang sedang melaksanakan shalat, begitu taat dan bersungguh-sungguh untuk mengikuti seluruh proses sejak dari takbir sampai salam. Tidak pernah kita dengar ada orang yang menipu jumlah rakaat dalam shalat walaupun dia shalat sendirian. (Toto Tasmara, 2001: 191).

Shalat ritual telah melahirkan nuansa kejujuran dan melaksanakan seluruh kewajibannya dengan penuh rasa tanggung jawab. Bagi orang-orang yang shiddiq, esensi shalat tidak berhenti sampai ucapan assalamu'alaikum, tetapi justru ucapan itu merupakan awal bagi dirinya untuk membuktikan hasil shalatnya dalam kehidupan secara aktual dan penuh makna manfaat.

\section{Istiqomah (keteguhan/ kemantapan)}

Menanamkan sikap istiqomah ini, merupakan bagian dari proses "pendewasaan" peserta didik. Hal ini merupakan salah satu dari bagian tugas lembaga pendidikan untuk mempersipakan pesrta didik agar mereka meningkatan kemampuan merespon dan memecahkan masalah-masalah dirinya sendiri maupun orang lain. (Azyumardi Azra, 2008).

Istiqomah bukanlah berarti sebuah sikap yang jumud, tidak mau adanya perubahan (status quo), namun, sebuah kondisi yang tetap konsisten menuju arah yang diyakini dengan tetap terbuka ( openminded) terhadap gagasan inovatif yang akan menunjang atau memberikan kontribusi positif untuk pencapaian tujuannya.

Orang yang memiliki sifat istiqomah ini, akan terlihat dari beberapa cirri, diantara lain: Pertama, Mereka mempunyai tujuan, sikap istiqomah hanya mungkin merasuki jiwa seseorang bila mereka mempunyai tujuan yang ingin dicapai, sehingga dengan menetapkan tujuan, mereka mampu merencanakan setiap tindakannya serta mengelola asset dirinya agar bekerja lebih efektif dan efisien. Kedua, mereka orang-orang yang kreatif, mereka yang iatiqomah akan tampak dari kreatifitasnya, yakni kemampuan untuk menghasilkan sesuatu melalui gagasan-gagasannya yang segar. Mereka mampu melakukan deteksi dini terhadap permasalahan yang dihadapinya, haus akan informasi, dan mempunyai rasa ingin tahu yang sangat besar (curiousity) serta tidak takut pada kegagalan. Ketiga, mereka sangat menghargai waktu. Waktu adalah asset Ilahiah yang paling berharga. Orang yang mempunyai kecerdasan ruhani dan rasa tanggung jawab yang mengilahi, ia tidak akan mungkin menyia-nyiakan waktu, membengkalaikan pekerjaan, dan menumpuk-numpuk tugas. Keempat, mereka bersikap sabar, karena sabar ini adalah kunci dari kecerdasan emosional. Sabar meruapakn suasana batin yang tetap tabah, istiqomah pada awal dan akhir ketika menghadapi tantangan, dan mengemban tugas dengan hati yang tabah dan optimis.

\section{Fathanah}

Fathanah merupakan kecerdasan yang mencakup kecerdasan intelektual, emosional, dan terutama spiritual. Seseorang yang memiliki sikap fathanah, tidak saja menguasai bidangnya, tetapi 
memiliki dimensi ruhani yang kuat. Keputusan-keputusannya menunjukkan warna kemahiran seorang professional yang didasarkan pada sikap moral atau akhlak yang luhur. Seorang yang $f a-$ thanah itu tidak saja cerdas, tetapi juga memiliki kebijakan atau kearifan dalam berpikir dan bertindak.

Mereka yang memiliki jiwa $f a-$ thanah mampu belajar dan menangkap peristiwa yang ada di sekitarnya, kemudian menyimpulkannya sebagai pengalaman berharga dan pelajaran yang memperkaya khazanah pemikirannya. Mereka tidak segan untuk belajar dan mengajar. Karena bagi mereka, hidup semakin berbinar ketika seseorang mampu mengambil pelajaran dari peristiwaperistiwa tersebut.

Sikanya proaktif, yaitu ingin memberikan makna yang berarti bagi lingkungannya. Dia ingin memahami orang lain sebelum dirinya dipahami, sehingga sikapnya yang proaktif itu menyebabkan dirinya selalu berorientasi pada prestasi. Sikap yang positif menumbuhkan kekayaan batin yang kuat untuk belajar dan menangkap segala fenomena yang ada dengan sikapnya yang arif. Hal ini telah dinyatakan Allah dalam Al-Qur' an “"

"Hanyalah orang-orang yang berakal ( ulul-albaab) yang dapat mengambil pelajaran." (Ar-Rad:19)

Mereka yang berjiwa fathanah mampu menempatkan dirinya sebagai fokus perhatian lalu menjadikan dirinya sebagi figure teladan atau uswatun hasanah karena kemahirannya (Profesionalisme) dan kepribadiannya yang mampu menumbuhkan situasi yang menentramkan. Orang dengan kecakapan seperti ini, akan melakukan hal-hal sebagai berikut:

1) Sadar tentang kekuatan-kekuatan dan kelemahannya.

2) Menyempatkan diri untuk merenung dan belajar dari pengelaman.
3) Terbuka terhadap umpan balik yang tulus, bersedia menerima perspektif yang baru, ma uterus belajar, dan mengembangkan diri sendiri.

4) Mampu menun jukkan rasa humor dan bersedia memandang diri sendiri dengan perspektif yang luas. (Daniel Goleman, 1991: 30)

\section{Amanah}

Indikator lain dari seseorang yang memiliki kecerdasan ruhaniah adalah sikapnya yang selalu ingin menampilkan sikap yang bisa dipercaya, menghormati dan dihormati, dan bertanggung jawab (taqwa).

\section{Tablig}

Fitrah manusia sejak kelahiraannya adalah kebutuhan dirinya kepada orang lain. Kita tidak mungkin dapat berkembang dan survive kecuali ada kehadiran orang lain. Kita dapat mengatakan "aku ada karena aku memberikan makna bagi orang lain, sebagaimana Rasulullah saw bersabda, yang artinya: "Engkau belum disebut sebagai orang yang beriman kecuali engkau mencintai orang lain sebagaimana mencintai dirimu sendiri."

Ucapan Rasulullah ini memberikan makna bahwa seseorang tidak mungkin berkembang dan mempunyai kualitas unggul kecuali dalam kebersamaan. Itulah sebabnya, seorang muslim tidak mungkin bersikap egois atau hanya mementingkan dirinya sendiri.

Orang yang mempunyai sikap tablig ini akan terlihat dalam berbagai kemampuan, diantaranya adalah: Pertama, kemampuan berkomunikasi (communication skill). Orang yang memiliki sikap tablig mampu membaca suasana hati orang lain dan berbicara dengan kerangka pengalaman serta rujukan atau tingkat pendidikan lawan bicaranya. Kedua, kuat menghadapi tekanan, me- 
reka yang mempunyai sikap tablig ini mempunyai sikap percaya diri yang berlandaskan pada iman, sehingga segala bentuk tekanan tidak dijadikannya sebagai kendala, tetapi sebuah tantangan yang akan membentuk kepribadian dirinya menjadi lebih cenerlang. Ketiga, kerja sama yang harmoni. Mereka yang memiliki sikap tablig memiliki kemampuan bekerja sama sebagai bagian dari sikap kepemimpinannya. Mereka melihat orang lain sebagai bagian dari jati dirinya sendiri dalam pengertian bahwa dirinya hanya mungkin berkembang bersama dan karena kualitas orang lain di sekitarnya.

\section{Menghindari Dikotomi Antara Akhlak dan Ibadah dalam Praktek}

Akhlak merupakan kondisi utama dalam pembentukan pribadi manusia yang seutuhnya. Kepribadian yang utuh hanya mungkin dapat dibentuk melalui pengaruh lingkungan dan pendidikan. Bila terjadi pemisahan antara akhlak dan ibadah, maka akan melahirkan dua tipe manusia, yang keduanya jauh dari konsep kecerdasan ruhaniah. Kedua tipe manusia tersebut adalah: Pertama, hamba yang buruk akhlaknya. Kedua, hamba yang baik akhlaknya, tapi buruk ibadah.

Keterkaitan antara taqwa dan akhlak itu sejajar dengan keterikatan iman dan amal, antara habl min Allah dan hunubgan dengan manusia, antara takbir (dalam permulaan shalat, sebagai tanda dimulainya seseorang hamba mengadakan hubungan dengan Allah) dan taslim (dalam akhir shalat sebagai tanda dimulainya hubungan antara sesama manusia, bahkan sesama makhluk), dan antara shalat itu sendiri (sebagai suatu bentuk hubungan dengan Allah) dengan zakat (sebagai suatu bentuk hubungan dengan kemanusiaan), (Nurcholish Madjid, 2000, 108)

Pendidikan akhlak dalam rangka pencapaian akhlak al-karimah ini bertujuan agar manusia (peserta didik) mampu mengaplikasikan nilai-nilai Ilahiyat dalam menjalin hubungan antara sesama manusia atau sesama makhluk atas dasar ridha Allah. Pendidikan ini bisa diawali dengan pendidikan yang didasarkan konsep ihsan, yaitu dalam beribadah itu kita melihat Allah, kalau tidak sanggup membayangkan itu semua, yakinlah Allah pasti melihat kita. Sehingga dengan konsep ini tidak akan terjadi dikotomi antara akhlak dan ibadah dalam pengamalannya. InsyaAllah.

\section{PENUTUP}

Pendidikan yang berbasis kecerdasan ruhaniah itu pada dasarnya adalah pendidikan yang berusaha untuk mengintegralkan semua potensi atau kecerdasan yang telah diberikan oleh Alah kepada manusia. Sehingga dengan memadukan semua potensi itu, akan terlahirlah manusia-manusia paripurna (insan kamil), insan-insan yang mempunyai akhlak al-karimah, insan-insan yang cerdas ruhaninya. Untuk mencapai kecerdasan ruhani ini, dapat dilakukan dengan berbagai cara, diantara; meneladani dan mengaktualisasikan sikap Rasulullah dalam kehidupan sehari-hari, serta menghindari terjadinya dikotomi antara akhlak dan ibadah dalam pengamalannya.

\section{DAFTAR RUJUKAN}



Abdullah Idi. 2006. Revitalisasi Pendidkan Islam, Yogyakarta. Aqwam.

Ahmad Mubarok. 2010 Meraih Bahagia Dengan tasawuf, Jakarta: Dian Rakyat,

Amru Khalid. 2006 Semulia Akhlak Nabi $S A W$. Solo: Aqwam.

Ary Ginanjar Agustian. 2004 Rahasia Sukses Membangkitkan ESQ POWER Sebuah Inner Journey Melalui Ihsan, Jakarta: Arga.

Ary Ginanjar Agustian. 2001. Rahasia Sukses membangun Kecerdasan Emosional dan Spiritual Berdasarkan 6 Rukun Iman dan 5 Rukun Islam, Jakarta : Arga.

Azyumardi Azra. 2002. Pendidikan Islam Tradisi dan Modernisasi Menuju Millenium Baru, Jakarta : Logos.

Daniel Goleman. 1999. Working With Emotional Intellegence, New York : Bantam Books.
Erbe Sentanu. 2007. Quantum Ikhlas Teknologi Aktivasi kekuatan Hati, Jakarta ; Elex Media Komputindo.

Hasan langgulung. 1991. Kreativitas dan Pendidikan Islam, Analisa Psikologi dan Falsafah, Jakarta: Pustaka al-Husna.

Nurcholish Madjid. 2000. Masyarakat Religius, Jakarta: Paramadina.

Samsul Nizar. 2008. Memperbincangkan Dinamika Intelektual dan Pemikiran Hamka tentang Pendidikan Islam, Jakarta: Prenada Media Group.

Toto Tasmara. 2001. Kecerdasan Ruhaniah, membentuk Kepribadian yang Bertanggung jawab, Profesional dan Berakhlak, Jakarta: Gema Insani Press.

Zuharini,dkk, 1992. Filsafat Pendidikan Islam, Jakarta; Bumi Aksara. 